\title{
LEVELS OF MONOCYTE CHEMOATTRACTANT PROTEIN-1 DIFFER FROM THE NORM IN PATIENTS WITH SUDDEN SENSORINEURAL HEARING LOSS
}

\author{
Frank Haubner ${ }^{1}$, Ludwig Martin ${ }^{1}$, Thomas Steffens ${ }^{1}$, Christian Rohrmeier ${ }^{1}$, Juergen Strutz ${ }^{1}$, \\ Tobias Kleinjung ${ }^{2}$ \\ ${ }^{1}$ Department of Otorhinolaryngology, University of Regensburg, Germany \\ ${ }^{2}$ Department of Otorhinolaryngology, University of Zurich, Switzerland
}

Corresponding author: Frank Haubner, Department of Otorhinolaryngology, University of Regensburg, Franz-Josef-Strauss-Allee 11, 93053 Regensburg, Germany, Phone: +49-941-9449515, Fax: +49-941-9449415, e-mail: frank.haubner@klinik.uni-regensburg.de

\section{Abstract}

Background: The aim of this study was to evaluate the role of cytokines and soluble adhesion molecules in patients with sudden sensorineural hearing loss (SSNHL) with respect to their pure-tone audiometry values.

Material and Methods: This study analyses blood samples of 51 patients with SSNHL. Serum levels of ICAM-1, VCAM-1, E-selectin, IL-6, IL-8, and MCP-1 were evaluated by ELISA. Pure-tone audiometry data were compared before and after a systemic steroid treatment regimen. The subjects with SSNHL were compared to a control group of 44 patients with normal hearing and matching age and gender. The data complete our previous data collection.

Results: There is trend toward suppressed levels of MCP-1 in sera of SSNHL patients. There were no statistically significant differences concerning ICAM-1, VCAM-1, E-selectin, IL-6, IL-8, and MCP-1 between SSNHL patients and controls. Puretone audiometry of the SSNHL group showed a significant improvement in hearing after systemic steroid therapy and a median follow-up of 4 months.

Conclusions: Further prospective studies are necessary to prove the role of MCP-1 and other cytokines in SSNHL in order to develop adequate treatment regimens.

\section{СОДЕРЖАНИЕ МОНОЦИТАРНОГО ХЕМОАТТРАКТИВНОГО ПРОТЕИНА-1 ОТЛИЧАЕТСЯ ОТ НОРМЫ У ПАЦИЕНТОВ С ВНЕЗАПНОЙ ПЕРЦЕПТИВНОЙ ТУГОУХОСТЬЮ}

\section{Резюме}

Введение: Целью данного исследования являлась оценка роли цитокинов и растворимых внутриклеточных молекул у пациентах с внезапной перцептивной тугоухостью (SSNHL) относительно их результатов тональной аудиометрии.

Материал и Методы: В данном исследовании рассмотрено образцы крови 51 пациента с SSNHL. Cтепень содержания ICAM-1, VCAM-1, E-селектина, IL-6, IL-8 и MCP-1 в сыворотке было оценены с помощью энзим-связанного иммуносорбентного анализа (ELISA). Данные тональной аудиометрии были сравнены до и после систематического лечения стероидами. Пациенты с SSNHL были сравнены с контрольной группой из 44 пациентов с нормальным слухом и соответствующим возрастом и полом. Данные заканчивают наш предыдущий сбор данных.

Результаты: Существует тенденция к меньшему содержанию MCP-1 в сыворотках пациентов с SSNHL. Hе выявлено никаких статистически значимых различий относительно ICAM-1, VCAM-1, Е-селектина, IL-6, IL-8 и MCP 1 между пациентами с SSNHL и из контрольной группы. Тональная аудиометрия группы с SSNHL показала существенное улучшение слуха после систематической терапии стероидами и в среднем на протяжении 4 месяцев последующей обсервации.

Заключения: Необходимы дополнительные последующие исследования для того, чтобы выявить роль МСР-1 и других цитокинов у пациетов с SSNHL для развития соответствующиего лечения. 


\section{LOS NIVELES DE PROTEÍNA QUIMIOTÁCTICA DE MONOCITOS 1 DIFERENCIAN DE LA NORMA EN PACIENTES CON HIPOACUSIA SENSORINEURAL SÚBITA}

\section{Extracto}

Introducción: El objetivo de este estudio era evaluar el papel de citocinas y moléculas de adhesión solubles en pacientes con hipoacusia sensorineural súbita (SSNHL) con respecto a sus resultados de la audiometría de tonos puros.

Material y Métodos: Este estudio analiza las muestras de sangre de 51 pacientes con SSNHL. Los niveles de ICAM-1, VCAM1, E-selectina, IL-6, IL-8 y MCP-1 en suero fueron evaluados por ELISA. Los resultados de la audiometría de tonos puros fueron comparados antes y después de un tratamiento de esteroide sistemático. Los pacientes con SSNHL eran comparados con un grupo de control de 44 pacientes con el oído normal y de edad y género correspondiente. Los datos completan nuestra recogida de datos anterior.

Resultados: Existe una tendencia a crecer de los niveles de MCP-1 en sueros de pacientes con SSNHL. No había ningunas diferencias estadísticamente significativas acerca de ICAM-1, VCAM-1, E-selectina, IL-6, IL-8 y MCP-1 entre pacientes con SSNHL y de grupo de control. La audiometría de tonos puros del grupo con SSNHL mostró un mejoramiento significativo del oído después de la terapia de esteroide sistémica y a continuación de 4 meses.

Conclusiones: Los estudios futuros son necesarios para demostrar el papel de MCP-1 y otros citocines en pacientes con SSNHL para desarrollar regímenes de tratamiento adecuados.

\section{Background}

Sudden sensorineural hearing loss (SSNHL) is a common disorder, but the exact causes of most SSNHL are still unknown. There are several hypotheses concerning the etiology of SSNHL, and an increased blood viscosity [1] in patients with SSNHL supports a vascular hypothesis. Other authors report that SSNHL co-occurring with hypertension, diabetes mellitus, or dyslipidemias seems to be associated with a higher prevalence of cerebral microangiopathy and with a slower hearing recovery [2]. The consequences are multiple treatment regimens usually based on applying steroids orally, intratympanically, or intravenously. The high spontaneous recovery rate of SSNHL makes the true usefulness of a specific treatment hard to prove [3].

Cytokines [4] and soluble adhesion molecules [5] seem to play a major role in inner ear pathologies and in recovery processes, which is why this study focused on the role of these proteins. Monocyte chemoattractant protein-1 (MCP-1) has been discussed in several disorders in the past: atherosclerosis, diabetes mellitus, angiogenesis, and inflammatory tissue reactions seem to be modulated by this chemokine [6].

MCP- 1 is a member of the $\mathrm{C}-\mathrm{C}$ class of the beta chemokine family and one of the key factors involved in the initiation of inflammation. It triggers chemotaxis and transendothelial migration of monocytes to inflammatory lesions by interacting with the membrane CC chemokine receptor 2 (CCR2) in monocytes. MCP-1 is secreted by fibroblasts, endothelial cells, vascular smooth muscle cells, monocytes, T cells, and other cell types[7].

The role of MCP-1 in SSNHL is presently unknown. As previously reported [8], we found no statistically significant differences concerning soluble adhesion molecules and cytokines in our study population which included 35 patients and matching control subjects. The aim of the present study was to evaluate the role of these molecules in SSNHL pathogenesis by using an increased number of blood samples.

\section{Material and Methods}

In addition to the 35 patients of our previous work, 16 more patients affected by a unilateral SSNHL were included in this study $(n=51)$. Written consent was obtained for the entire study by the Institutional Review Board of the University of Regensburg (number 08/120). Inclusion criteria for this study were the same as previously described: (1) hearing loss of more than $30 \mathrm{~dB}$ HL in more than 3 contiguous frequencies according to the accepted criteria of the National Institute of Health; (2) age-equivalent hearing of the non-affected ear; (3) no history of hearing loss or ear surgery in the past. In addition, 9 extra controls and 35 participants from our previous data collection were included as a control group with matching age and sex proportions $(n=44)$; they had no history of hearing loss and age-equivalent hearing according to hearing levels of ISO 7029. Pure-tone audiometry and standard audiovestibular investigations were obtained for each patient and control subject as previously described. All SSNHL patients received a treatment regimen including intravenous infusion of prednisolone, 3\% hydroxyethyl starch and magnesium for 5 days, followed by oral steroids for one more week.

Hearing loss was documented by pure-tone audiometry on the first day of the SSNHL diagnosis and 3 to 6 months later. The mean hearing loss in the three most affected frequencies was analysed.

At the the first consultation, blood samples were taken before therapy started. Levels of soluble adhesion molecules ICAM-1 (intercellular adhesion molecule 1), VCAM-1 (vascular cell adhesion molecule 1), E-selectin (endothelial selectin), and concentrations of 


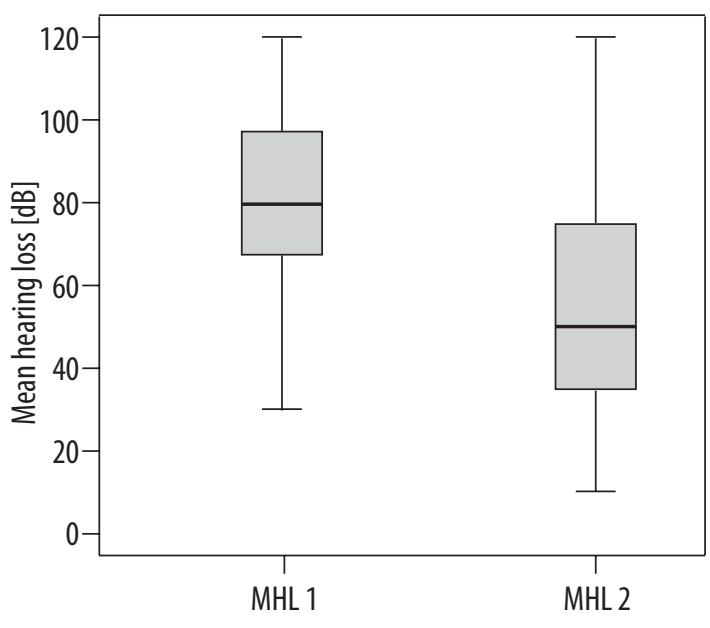

Figure 1. Box plots of mean average hearing loss before (MHL 1) and after (MHL 2) treatment in the follow-up examination. MHL 1 is calculated as the mean hearing loss in the three most affected frequencies. MHL 2 represents the mean values of the same frequencies in the follow-up. Box plots include median, $25 \% / 75 \%$ percentile (boxes), and minimum/maximum values (whiskers).

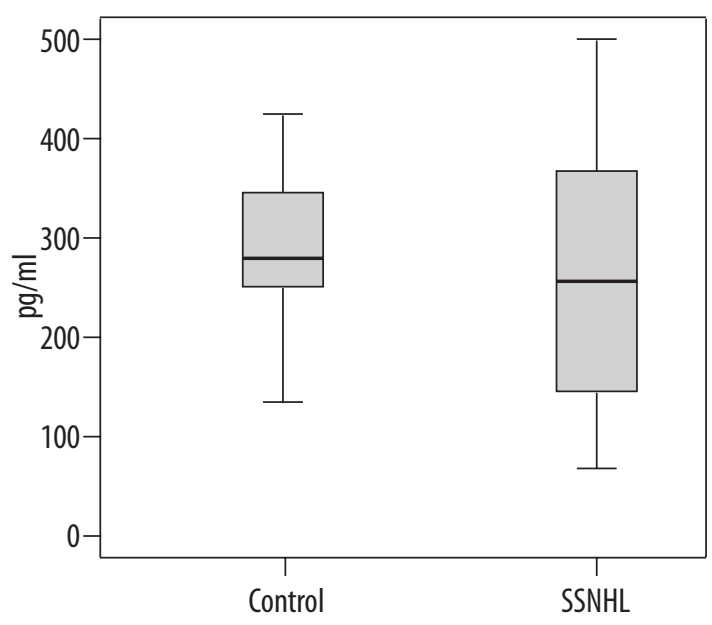

Figure 2. Box plots of serum MCP-1 levels in control subjects and SSNHL patients. Box plots include median, $25 \% / 75 \%$ percentile (boxes), and minimum/maximum values (whiskers).

IL-6 (interleukin 6), IL-8 (interleukin 8), and MCP-1 (monocyte-chemoattractant protein 1) were measured using established enzyme-linked-immunosorbent assays (R\&D Systems QUANTAKINE, Human sVCAM-1 Immunoassay, Human sICAM-1/CD54 Immunoassay, Human sE-Selectin/CD62E Immunoassay, Human CCL2/MCP-1 Immunoassay, Siemens IMMULITE 2000 IL-6, DPC IMMULITE IL-8) according to the manufacturer's instructions.

Statistical analysis was performed with SPSS 18.0 for Windows (SPSS Inc., Chicago, USA). Statistical significance was set at $p<0.05$.

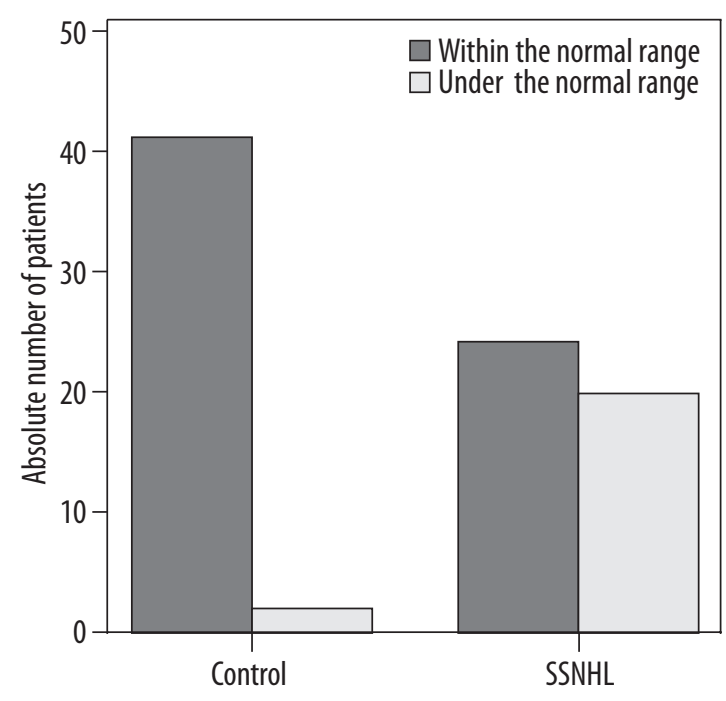

Figure 3. Absolute number of SSNHL patients and control subjects with MCP-1 serum levels within and under the normal range of the present assay (200-722 pg/mL).

\section{Results}

A total number of 51 patients with SSNHL were included in the study and compared to 44 subjects with normal hearing.

The median age in the patient group was 56 years (22-87 years) and there were 32 males and 19 females. The median age in the control group was 48 years (18-68 years) including 29 males and 15 females. There were no statistically significant $(p>0.05)$ differences in age or gender between the groups. Risk factors such as diabetes, hypertension, and smoking habits were similar in both groups. Exactly 26 SSNHL patients agreed to a control examination and were re-evaluated by pure-tone audiometry after a follow-up of more than 3 months. The mean hearing loss in the three most affected frequencies was analysed. There was a statistically significant $(p<0.001)$ improvement of hearing in the follow-up examination (Figure 1).

As already documented in our previous analysis of 35 patients and controls [8], the levels of soluble intercellular adhesion molecule-1, soluble vascular cell adhesion molecule-1, endothelial selectin, and MCP-1 in sera of SSNHL patients (Figure 2) were not significantly different from those of the control group. However, there was an obvious difference in the number of subjects presenting with suppressed MCP-1 values in the SSNHL group compared to the control group. With respect to the normal range, there were more SSNHL patients with suppressed levels of MCP-1 than the controls (Figure 3). This difference was highly significant in the chi-square test $(p<0.001)$. The normal range of the MCP- 1 assay was determined on the basis of 37 samples from apparently healthy volunteers according to information of the manufacturer (Human CCL2/MCP-1 Immunoassay; QUANTAKINE, R\&D Systems, Minneapolis, USA). The similar normal range values were published in a study of Takebayashi et al. [9]. 
The additional recruitment of 16 patients and 9 controls did not result in a statistically significant difference concerning the analysed cytokines IL- 6 and IL-8.

\section{Discussion}

It is assumed that microcirculation disturbances conditioned by an endothelial dysfunction might represent an important cause for the development of SSNHL. Adhesion molecules favoring interaction between leukocytes and endothelial cells are early markers of endothelial damage. The sudden onset and the fact that the inner ear vascularisation is provided by a functional end artery might be an indication of similar vascular pathogenesis in SSNHL and cardiovascular disease. In contrast to Quaranta et al. [5], who analysed 37 SSNHL patients, VCAM-1 was not significantly higher in our group of 51 SSNHL patients.

Our present study (including the previous data collection [8]) does not support the hypothesis that endothelial dysfunction might be involved in the etiology of SSNHL. We could not document elevated levels of soluble adhesion molecules in SSNHL patients as compared to a control group of subjects with normal hearing.

Cytokines such as IL-6, IL-8, and MCP-1 are involved in leukocyte adherence and favour cellular extravasation into inflamed tissue [10]. Inflammatory cytokines play critical roles in a variety of cellular processes. Knowledge about the identity and cellular localisation of these compounds within the ear is sparse. MCP-1 also seems to be involved in inner ear pathologies $[11,12]$. Whether this molecule takes part in SSNHL pathogenesis is still unknown. We can see a trend toward different levels of MCP-1 in the SSNHL group. With respect to the accepted normal range, we found more levels under the estimated value of $200 \mathrm{pg} /$ $\mathrm{mL}$. One control and 7 patients were not included in this analysis because of MCP-1 levels below the detection limit of our assay. This fact may support our hypothesis of suppressed MCP-1 levels in patients with SSNHL.

The intake of antihypertensive drugs and comorbidities such as diabetes mellitus can influence MCP-1 serum levels $[13,14]$, but there was no association between medication or comorbidities and this effect in our study. Bianchi et al. [15] report the first observation of the chemokine MCP-1 as an inner-ear-derived, neurite-promoting molecule. In a cell culture model they describe MCP-1 as the growth factor for outgrowth from the statoacoustic ganglion. With respect to the idea of MCP-1 as a nerve-promoting factor in the inner ear, the deficient spontaneous recovery of patients suffering from SSNHL might be explained by their suppressed serum levels of this cytokine.
While this observation may help our understanding, the pathology of SSNHL is still unclear and further research concerning the role of MCP-1 in SSNHL is needed. With more research, the roles of MCP-1 in various clinical conditions (e.g. diabetes mellitus, atherosclerosis, infection and inflammation) will continue to be elucidated. However, the critical question that still needs to be addressed is whether chemokine expression is pathogenetically responsible for any of the manifestations of these diseases. This has been very difficult to address in humans because of the apparent absence of genetic abnormalities involving chemokines and their receptors [6].

The deficient understanding of SSNHL might be one reason for the variety of therapeutic regimens. The SSNHL patients in our study were treated with hydroxyethyl starch, intravenously administered corticosteroids, and magnesium. A significant improvement of hearing was observed in the re-examination of 26 patients after a median follow-up of 4 months. Usually there is no further improvement in hearing 2 weeks after an event of SSNHL [16]. The relatively low rate of patients in the control examination is due to the fact that many of the patients live far away from our institution. There are little data concerning the evidence of magnesium and other mineral supplements in SSNHL, but also other authors recommend magnesium substitution [17]. A recent systematic literature review concluded that a direct causal link between SSNHL and previously discussed etiologies remains elusive [18]. That is why further investigations and consideration of different factors such as growth factors are necessary.

\section{Competing interests}

The authors declare they have no competing interests.

\section{Authors' contributions}

FH and TK developed the design of the study. LM and CR collected and performed the analysis of the patient data including ELISA and hearing tests. TS performed the statistical analysis. JS, TK, and FH participated and helped to draft the manuscript. All authors read and approved the manuscript.

\section{Acknowledgements}

The authors want to thank Daniela Biermeier from the Institute of Clinical Chemistry, University of Regensburg, who performed the measurements of adhesion molecules and cytokines.

\section{References:}

1. Ohinata $\mathrm{Y}$, Makimoto $\mathrm{K}$, Kawakami $\mathrm{M}$ et al: Blood viscosity and plasma viscosity in patients with sudden deafness. Acta Otolaryngol, 1994, 114(6): 601-7

2. Nagaoka J, Anjos MF, Takata TT et al: Idiopathic sudden sensorineural hearing loss: evolution in the presence of hypertension, diabetes mellitus and dyslipidemias. Braz J Otorhinolaryngol, 76(3): 363-69
3. Canis M, Heigl F, Hettich R et al: [Fibrinogen/LDL apheresis for treatment of sudden hearing loss: An observational study on 152 patients.]. Hno, 2008, 56(9): 961-66

4. Adams JC: Clinical implications of inflammatory cytokines in the cochlea: a technical note. Otol Neurotol, 2002, 23(3): $316-22$ 
5. Quaranta N, Ramunni A, Brescia P et al: Soluble intercellular adhesion molecule 1 and soluble vascular cell adhesion molecule 1 in sudden hearing loss. Otol Neurotol, 2008, 29(4): $470-74$

6. Yadav A, Saini V, Arora S: MCP-1: chemoattractant with a role beyond immunity: a review. Clin Chim Acta, 2010, 411(21-22): 1570-79

7. Melgarejo E, Medina MA, Sanchez-Jimenez F, Urdiales JL: Monocyte chemoattractant protein-1: a key mediator in inflammatory processes. Int J Biochem Cell Biol, 2009, 41(5): 998-1001

8. Haubner F, Martin L, Steffens T et al: The role of soluble adhesion molecules and cytokines in sudden sensorineural hearing loss. Otolaryngol Head Neck Surg, 2011; 144(4): 575-80

9. Takebayashi K, Suetsugu M, Matsumoto $S$ et al: Effects of rosuvastatin and colestimide on metabolic parameters and urinary monocyte chemoattractant protein-1 in type 2 diabetic patients with hyperlipidemia. South Med J, 2009, 102(4): 361-68

10. Lukacs NW, Strieter RM, Elner V et al: Production of chemokines, interleukin-8 and monocyte chemoattractant protein-1, during monocyte: endothelial cell interactions. Blood, 1995; 86(7): 2767-73
11. Moon SK, Woo JI, Lee HY et al: Toll-like receptor 2-dependent NF-kappaB activation is involved in nontypeable Haemophilus influenzae-induced monocyte chemotactic protein 1 up-regulation in the spiral ligament fibrocytes of the inner ear. Infect Immun, 2007; 75(7): 3361-72

12. Moon SK, Park R, Lee HY et al: Spiral ligament fibrocytes release chemokines in response to otitis media pathogens. Acta Otolaryngol, 2006; 126(6): 564-69

13. Ogino K, Kato M, Furuse $Y$ et al: Addition of losartan to angiotensin-converting enzyme inhibitors improves insulin resistance in patients with chronic heart failure treated without beta-blockers. Circ J, 2010; 74(11): 2346-52

14. Tretjakovs P, Jurka A, Bormane I et al: Relation of inflammatory chemokines to insulin resistance and hypoadiponectinemia in coronary artery disease patients. Eur J Intern Med, 2009; 20(7): 712-17

15. Bianchi LM, Daruwalla Z, Roth TM et al: Immortalized mouse inner ear cell lines demonstrate a role for chemokines in promoting the growth of developing statoacoustic ganglion neurons. J Assoc Res Otolaryngol, 2005; 6(4): 355-67

16. Schreiber BE, Agrup C, Haskard DO, Luxon LM: Sudden sensorineural hearing loss. Lancet, 2010, 375(9721): 1203-11

17. Gordin A, Goldenberg D, Golz A et al: Magnesium: a new therapy for idiopathic sudden sensorineural hearing loss. Otol Neurotol, 2002; 23(4): 447-51

18. Chau JK, Lin JR, Atashband S et al: Systematic review of the evidence for the etiology of adult sudden sensorineural hearing loss. Laryngoscope, 2010, 120(5): 1011-21 